\title{
Kinerja kepala sekolah sebagai leader dalam Manajemen mutu terpadu di SD Muhammadiyah Pendowoharjo
}

\author{
Hafidh Nur Fauzi a,1,* \\ a SD Negeri Karangsari, Gg. Melati Rejowinangun Kotagede, Kota Yogyakarta, Yogyakarta 55171, Indonesia \\ 1 hafidhnurfauzi90@gmail.com \\ * corresponding author
}

\section{ARTICLE INFO}

\section{Article History}

Received: 27 of July, 2020 Revised: 15 of January, 2021

Accepted; 30 of January, 2021

Keyword: Schoo Leadership, Principal Performance, Total Quality Management

Kata Kunci

Kepemimpinan kepala sekolah, Kinerja kepala sekolah, Manajemen mutu terpadu

\section{ABSTRACT}

The performance of school principals is a key element in disseminating quality culture and integrated quality management. The aim of this research is to describe and analyze the performance of school principals related to integrated quality management. The research approach uses a qualitative research approach, a type of descriptive qualitative research method. Data collection was carried out by observation techniques, interview techniques, and documentation techniques. Data analysis used qualitative data analysis with the stages of data collection, data reduction, and conclusions. The data analysis uses some stages, they are; data collection, data reduction, and drawing conclusions. The results of this study indicate that the performance of the principal of SD Muhammadiyah Pendowoharjo as the leader in managing the school community empowers total quality management to achieve the expected school goals and strategic plans. The performance of the principal as a leader in developing the quality of education in an integrated manner is carried out by methods of; 1) disseminating the school's vision and mission, goals, and strategic plans to internal and external customers; 2) motivating teachers and education staff to perform optimally with measurable results; 3) providing guidance to teacherss and education staff with a structural and familial approach to contribute positively to the development of school quality; and 4) facilitating teachers and education personnel to improve self-development by participating in workshops and training activities.

\section{ABSTRAK}

Kinerja kepala sekolah merupakan elemen kunci dalam mensosialisasikan budaya mutu dan manajemen mutu terpadu. Penelitian yang telah dilakukan bertujuan untuk mendeskripsikan dan menganalisis kinerja kepala sekolah terkait pengelolaan manajemen mutu terpadu. Pendekatan penelitian yang telah dilakukan menggunakan pendekatan penelitian kualitatif, jenis metode penelitian kualitatif deskriptif. Pengumpulan data dilakukan dengan teknik pengamatan, teknik wawancara, dan teknik dokumentasi. Analisa data menggunakan analisis data kualitatif dengan tahapan koleksi data, reduksi data, dan pengambilan kesimpulan. analisis yaitu pengumpulan data, reduksi data, dan penarikan kesimpulan. Hasil penelitian ini menunjukkan bahwa kinerja kepala sekolah SD Muhammadiyah Pendowoharjo sebagai leader mengelola warga sekolah memberdayakan manajemen mutu terpadu untuk mencapai tujuan sekolah dan rencana strategis yang diharapkan. Kinerja kepala sekolah sebagai leader dalam mengembangkan mutu pendidikan secara terpadu dilakukan dengan cara; 1) melaksanakan sosialisasi visi-misi, tujuan, dan rencana strategis sekolah kepada pelanggan internal dan eksternal; 2) memotivasi tenaga pendidik dan kependidikan agar berkinerja secara optimal dengan capaian yang terukur; 3) melakukan pembinaan terhadap tenaga pendidik dan kependidikan dengan pendekatan struktural dan kekeluargaan agar berkontribusi positif terhadap pengembangan mutu sekolah; dan 4) memfasilitasi guru-guru dan tenaga kependidikan untuk meningkatkan pengembangan diri dengan mengikuti kegiatan workshop dan pelatihan.

This is an open access article under the $\mathrm{CC}-\mathrm{BY}-\mathrm{SA}$ license. 


\section{Pendahuluan}

Mutu sekolah yang rendah masih menjadi problem di institusi pendidikan pada umumnya. Faktor-faktor yang menyebabkan rendahnya mutu pendidikan yaitu; pertama, kebijakan yang diambil oleh pemerinta dan masyarakat dalam penyelenggaraan pendidikan secara nasional mengugunakan model pendekatan education production function dengan pelaksanaan analisis yang tidak konsekuen dan cenderung berubah-rubah; kedua, pola penyelengaaraan pendidikan berpusat pada kebijakan pemerintah, yang demikian itu berimplikasi pada pengembangan sekolah sebagai pelaksana cenderung pasif dan sangat tergantung pada birokratisasi; dan ketiga, keterlibatan dan kontribusi masyarakat dalam penyelenggaraan pendidikan masih pada kategori rendah [1].

Untuk mengaktualisasikan karakter dari manajemen mutu terpadu diperlukan peran pimpinan. Dalam diri pemimpin terdapat suatu pola kepemimpinan yang berfungsi untuk mengarahkan warga organisasi agar mencapai visi-misi dan tujuan bersama. Efektifitas kepemimpinan sangat berpengaruh terhadap proses manajemen yang direncanakan. Ekosiswoyo (2007) mengungkapkan kebutuhan yang tinggi untuk mendukung proses peningkatan kualitas pendidikan adalah faktor kepemipimpinan [2]. Pemimpin adalah seorang yang memiliki kapasitas dan kemampuan untuk memberikan pengaruh dan mempengaruhi perilaku orang lain dalam berkinerja, yaitu dengan memberdayakan kekuasaan yang diamanahkan sesuai dengan fungsi dan jabatannya. Adapun kekuasaan merupakan kemampuan untuk memberikan arahan dan memberikan pengaruh kepada bawahan terkait dengan pekerjaan-pekerjaan yang harus dilaksanakan. Kepemimpinan yang efektif sangat terkait dengan ketersediaan sumber kekuasaan yang dimiliki oleh pimpinan.

Mulyasa (2011) mengungkapkan bahwa kepala sekolah yang efektif diharuskan untuk memahami tiga hal penting yaitu; 1) alasan akan pentingnya pendidikan yang berkualitas sebagai kebutuhan bagi sekolah; 2) tindakan-tindakan yang mutlak dilakukan untuk menjamin peningkatan mutu dan produktifitas kinerja sekolah; dan 3) memiliki pengetahuan tentang cara-cara untuk mengelola lembaga yang efektif untuk mencapai prestasi yang unggul [1]. Abdullah (2017) menyebutkan kontribusi kepemimpinan kepala sekolah yang signifikan dalam peningkatan manajemen mutu pendidikan, selain faktor pendukung profesionalisme guru, dan partisipasi masyarakat [3]. Gaol (2017) mengungkapkan gaya kepemimpinan yang dibutuhkan untuk mengelola sekolah gar efektif dengan mengkombinasikan gaya kepemimpinan manajerial, transformasional, transaksional, pengajaran yang positif. Manik dan Bustomi (2011), Setiyati (2014) mengungkapkan suatu temuan penelitian peranan kepemimpinan yang signifikan terhadap pengelolaan guru yang dalam hal ini adalah kinerja guru [4][5].

Kepala sekolah sebagai pimpinan masih sering menjadi pembahasan dalam diskusi-diskusi terkait peranannya dalam mengelola lembaga pendidikan. Terlebih apabila dihubungkan dengan mutu lembaga pendidikan yang menjadi tanggungjawabnya. Beberapa kepala sekolah berhasil mengelola sumber daya yang dimiliki sehingga sekolahnya bermutu dan unggul, tetapi tak jarang dan bahkan banyak kepala sekolah yang "gagal" dalam arti sekolah yang dikelola stagnan cenderung tidak berkembang. Mengutip ungkapan seorang bijak, bahwa "Seseorang yang berkinerja hari ini lebih meningkat dari hari-hari yang lalu, maka dia adalah orang yang mendapatkan keberuntungan. seseorang yang berkinerja hari ini sama seperti yang kemarin, maka dia adalah orang yang mendapatkan kerugian. Seseorang yang berkinerja hari ini lebih buruk dari pada hari-hari yang lalu, maka ia adalah kategori orang yang terkutuk". Makna dari ungkapan ini adalah kinerja yang tidak menunjukkan peningkatan atau "sama-sama saja", bahkan menurun daripada kondisi sebelumnya, maka demikian itu menunjukkan kinerja yang gagal, apa lagi jika lebih buruk dari kemarin

Pada pelaksanaannya, banyak ditemukan kegiatan manajerial yang dilakukan oleh pimpinan atau kepala sekolah tidak dilandasi dengan pengetahuan manajemen pendidikan yang baik. Selain daripada itu, kesulitan yang dihadapi dalam implementasi TQM adalah kesulitan dalam menentukan kualitas lulusan dari sisi kualitas [6]. Dampaknya adalah kinerja sekolah dalam mencapai tujuan yang direncanakan cenderung tidak efektif dan efisien, terjadi banyak "pemborosan" sumber daya, mutu yang tidak berkualitas, dan tingkat kepercayaan diri yang rendah dari pihak pengelola, peserta didik, dan pengguna. Konsep manajemen pendidikan dan manajemen mutu pendidikan menjadi keharusan untuk dipahami dan diimplementasikan oleh kepala sekolah sebagai pengelola sekolah. Demikian itu mendukung dan menunjang kinerja sekolah dalam mendorong dan memberikan dukungan bagi para guru dan tenaga kependidikan. Subjektifitas menjadi problem bagi kepala sekolah yang sering muncul dan mengganggu kinerja sekolah. Secara substantif, pengelolaan 
sekolah yang cenderung berpola tingkat desentralisasi rendah, terpusat pada pimpinan atau mono leadership merupakan konsekuensi logis dari pengelolaan sekolah yang tidak berorientasi mutu.

Pada umumnya, sekolah menjadi tempat dilaksanakannya proses pendidikan dan pembelajaran dengan tujuan dan proses rekayasa pembentukan karakter dan transfer pengetahuan. Sekolah juga menjadi sarana interaksi antara guru dengan siswa yang dinamis dan interaktif. Lebih dari hal tersebut, sekolah diharapkan muncul sebagai institusi yang memiliki peranan yang signifikan dalam menginternalisasikan norma-norma dan pengetahuan, serta budaya, yang mendukung suatu sistem nilai yang terstruktur dan terencana. Institusi yang spesifik yang terdiri dari fungsi-fungsi pelayanan terhadap masyarakat merupakan salah satu definisi dari sekolah [7].

Sekolah harus dimaknai sebagai organisasi yang bergerak terdiri dari orang-orang yang bersamasama, memiliki cara atau strategi yang disepakati bersama, dan memiliki kesamaan tujuan dalam bidang pendidikan. Sekolah terbukti memiliki dampak yang tinggi dalam mengembangkan sumber daya manusia internal dan eksternal. Di sekolah, para siswa mendapatkan pengalaman pengembangan mental dan intelektual yang dibimbing oleh guru-guru dan pengelola sekolah untuk mencapai tujuan individu dan tujuan bersama. Tidak dapat dipungkiri bahwa problem sumber daya manusia masih menjadi problem yang tidak ada habisnya, demikian itu karena beragam yaitu kualitas sosial masyarakat, kesenjangan ekonomi yang tinggi, gizi yang tidak seimbang termasuk ketersediaan sumber makanan bergizi, kondisi lingkungan yang tidak sehat. Pengelolaan pendidikan dalam hal ini sekolah yang bermutu, diyakini sebagai usaha menurunkan masalah-masalah yang dihadapi masyarakat.

Pengelolaan mutu pendidikan pada institusi sekolah merupakan revolusi dan terobosan baru yang masih jarang dilakukan oleh pengelola. Tidak mudah untuk membangun budaya mutu, dibutuhkan waktu yang tidak cepat, perubahan sikap dari seluruh warga sekolah, investasi sumber daya manusia melalui proses sosialisasi dan treatment merubah prilaku budaya mutu, dan bahkan membiayai program pendidikan dan pelatihan. Banyak kegagalan dalam implementasi mutu, disebabkan komitmen yang rendah dari pimpinan sekolah dalam mengembangkan mutu sekolah. Komitmen yang kuat merupakan faktor kunci yang menuntut untuk ditransmisikan kepada warga sekolah agar tercipta mutu terpadu [8].

Membranding sekolah dengan kata kunci unggulan, mengembangkan budaya mutu, dan mengimplementasikan pola Total Quality Management merupakan usaha untuk meningkatkan kualitas pendidikan. Implementasi manajemen mutu terpadu sangat membantu pengelola dalam mengidentifikasi dan mengukur ketercapaian mutu secara bertahap, dan membantu mewujudkan capaian visi-misi dan tujuan sekolah secara berkelanjutan. Dengan hal tersebut sekolah dapat meningkatkan kinerja yang sudah dilakukan, dan upaya perbaikan secara berkelanjutan dapat dirumuskan dan dikembangkan untuk selalu berkembang dan meningkat. Secara lebih spesifik, pencapaian sekolah dari sisi peserta didik, kurikulum, kualitas lulusan, ketersediaan sarana dan prasarana, dan kecukupan sumber daya dapat diusahakan dan dimaksimalkan. Sehingga tumbuh kembang sekolah menjadi fokus bersama, dan perkembangan peserta didik dari berbagai aspek akademis, kognitif, afektif, psikomotori dapat diukur dan berkembang.

Nawawi (2003) menegaskan tentang manajemen mutu di sekolah yang sangat mungkin diwujudkan dengan menyediakan sumber daya yang relevan dengan peningkatan kualitas proses dan hasil yang diharapkan [9]. Mutu membutuhkan kondisi lingkungan atau iklim organisasi yang kondusif untuk mengimplementasikan manajemen mutu secara optimla, didukung dengan sumber daya yang berkualitas. Sallis (2005) menekankan pentingnya nilai-nilai manajemen mutu pada organisasi, yang itu menjadi prinsip dasar tindakan dan upaya pencarian ketercapaian visi dan misi. Nilai-nilai mutu terpadu tersebut adalah upaya mengutamakan pelanggan, bekerja sistematis berdasarkan standar yang telah ditentukan dengan penuh integritas dan professional, orientasi tim dalam bekerja, komitmen dengan pengembangan yang terukur dan berkelanjutan, dan memberdayakan seluruh elemen untuk memberikan pelayanan yang optimal [10].

Manajemen mutu terpadu dapat dilihat dari program sekolah yang diselenggarakan untuk mencapai tujuan dari setiap program, dan pencapaian visi-misi sekolah secara konsisten. Pengelola sekolah merencanakan program dan kegiatan untuk memberikan solusi dari masalah yang dihadapi menggunakan beragam cara dan teknik sebagai usaha menjawab permasalahan. Pembentukan dan pemberdayaan team work yang baik dapat berkontribusi dalam menghadapi masalah. Segala 
aktivitas merupakan rangkaian sistem menuju pada tujuan yang sama. Faktor utama yang mendukung implementasi mutu terpadu adalah guru, tenaga pendidikan, dan pengelola sekolah yang berkualitas, pengembangan dan pemeliharaan sarana dan prasarana yang mencukupi dan proporsional terhadap kebutuhan, dukungan, trust dan kemauan masyarakat, wali murid dan stakeholder sekolah yang tinggi dan turut bekerjasama dan berkontribusi terhadap sekolah [11]. Senada dengan hal tersebut Fadhli (2017) mengungkapkan indikator mutu pendidikan sekolah yaitu; sekolah mendapatkan dukungan dari pemerintah, kepemimpinan kepala sekolah yang efektif, kinerja guru yang berkompetensi dan baik, perencanaan, pelaksanaan, dan evaluasi kurikulum yang relevan, lulusan yang berkualitas dalam arti sesuai dengan kebutuhan pengguna, budaya dan iklim organisasi yang adaptif dan efektif, dan dukungan masyarakat dalam hal ini orang tua siswa [12].

Penelitian terdahulu dilakukan oleh Juliantoro (2017) mengungkapkan bahwa peran kepemiminan dalam manajemen mutu pendidikan dilakukan dengan mengoptimalkan peran kepala sekolah sebagai edukator, manajer, administrator dan supervisor [13]. Fitrah (2017) mengungkapkan peran yang lain yaitu sebagai leader, innovator, dan motivator yang kemudian diikuti tindakan monitoring dan evaluasi terhadap visi-misi, program yang telah dilaksanakan [14]. Sedangkan penelitian yang telah dilakukan oleh peneliti, dan dituliskan pada artikel ini memiliki fokus pada kinerja kepemimpinan kepala sekolah sebagai leader.

Latar belakang tersebut menjadi dasar dari penelitian, penelitian yang telah dilakukan bertujuan untuk menyampaikan deskripsi dan analisis kinerja kepala sekolah sebagai leader dalam mengimplementasikan manajemen mutu terpadu di SD Muhammadiyah Pendowoharjo Sewon Bantul. Pemilihan terhadap sekolah tersebut didasari dengan pengetahuan peneliti terkait manajemen yang baik dalam mengelola sekolah, dibuktikan dengan; sekolah ini merupakan sekolah unggulan di Kecamatan Sewon ditunjukkan dengan siswa yang banyak, lokasi asal siswa dari berbagai daerah sekitar dan luar wilayah, tenaga pendidik dan kependidikan berkualifikasi sarjana sesuai dengan kompetensi dan kualifikasi regulasi pemerintah, kelengkapan sarana-prasarana yang dimiliki sekolah, ruang belajar yang representative untuk pembelajaran, pembelajaran berbasis ICT (Information Communication Technology), laboratorium yang dirawat dengan baik, perpustakaan dengan referensi dan bacaan yang terupdate, dan lokasi sekolah yang terjangkau oleh masyarakat. Dengan penelitian ini, diharapkan temuan secara teoritis dan praktis kinerja kepala sekolah dalam mengembangkan sekolah dengan pendekatan manajemen mutu terpadu.

\section{Metode Penelitian}

Penelitian ini memiliki tujuan untuk mengembangkan deskripsi deskripsi kinerja kepala sekolah yang dilakukan dalam mewujudkan pengelolaan mutu terpadu. Pendekatan penelitian yang dipilih untuk menjawab rumusan masalah penelitian adalah pendekatan penelitian kualitatif. Adapun jenis penelitian yang dipilih adalah jenis deskriptif, jenis ini memiliki tujuan mendeskripsikan objek penelitian dengan mengumpulkan data dan menguraikannya secara komprehensif dan teliti sesuai dengan masalah penelitian yang menjadi fokus[15]. Moeleong mengungkapkan bahwa penelitian deskriptif dengan pendekatan kualitatif dilakukan dengan melakukan pengamatan terhadap subjek penelitian secara wajar dalam kehidupan sehari-hari, berpartisipasi dan berinteraksi bersama subjek, melakukan wawancara, yang kemudian memaknai bahasa, prilaku dan perbuatan yang terbiasa, yang berhubungan dengan fokus penelitian [16].

Kategori penelitian yang telah dilakukan merupakan bagian dari penelitian lapangan atau dikenal dengan field research, mengingat yang dilakukan oleh peneliti adalah memotret, menggali data, dan mengelola informasi di lapangan. Pengumpulan data didapatkan dari wawancara terhadap informan yaitu kepala sekolah, observasi lingkungan di sekolah, dan dokumentasi dari kegiatan administratif yang dimiliki oleh lembaga. Data-data yang dikumpulkan bersifat kualitatif dari hasil wawancara, pengamatan, dan dokumen data penelitian.

Data yang didapatkan, kemudian dikumpulkan untuk dilakukan analisis data. Terkait kegiatan analisis data, data yang sudah dikumpulkan kemudian dilakukan reduksi data, data tersebut dikelompokkan, diarahkan dan bila perlu yang tidak penting dibuang. Setelah itu, peneliti data diolah untuk dibuat narasi sebagaimana kondisi subjek dan objek penelitian, berikutnya peneliti menarik kesimpulan dari data yang telah dinarasikan. Model induktif yang demikian itu merupakan 
karakter penelitian kualitatif yang mengumpulkan data-data khusus, kemudian diambil kesimpulan yang bersifat umum [16].

Waktu penelitian dilakukan pada tahun pembelajaran 2018-2019 di lokasi penelitian. Lokasi penelitian dilakukan di SD Muhammadiyah Pendowoharjo terletak di Desa Pendowoharjo, Kecamatan Sewon, Kabupaten Bantul. Sekolah ini dipilih dengan latar kepala sekolah yang baik dalam memimpin sekolah, sebagaimana hasil penilaian Majelis Dikdasmen Wilayah D.I Yogyakarta yang ditunjukkan dengan prestasi yang baik. Juga indikator kinerja sekolah yang baik ditunjukkan dengan minat masyarakat yang tinggi untuk mensekolahkan anak-anak mereka ke SD Muhammadiyah Pendowoharjo, sehingga jumlah peserta didik mengalami peningkatan peminat yang signifikan pada setiap tahunnya.

\section{Hasil dan Pembahasan}

\subsection{Manajemen Mutu Terpadu pada Institusi Pendidikan}

Total Quality Education merupakan konsep yang dekat dengan implementasi manajemen mutu terpadu pada institusi pendidikan. Istilah ini dikembangkan dari konsep Total Quality Management atau TQM pada bidang ekonomi. Populer dan dipraktikkan pada pengelolaan bisnis industri dan jasa. Melihat percepatan dan perkembangan dalam dunia bisnis yang signifikan dalam mengelola perusahaan, terbukti dengan pencapaian tujuan-tujuan bisnis, terfikir untuk mengelola lembaga pendidikan sebagaimana mengelola kelompok perusahaan, akan tetapi fokus yang diberikan adalah jasa pendidikan yang memiliki karakter dan nilai-nilai pendidikan sebagai dasar dan tujuan sebagai cara, wujud, dan tujuannya. Suryadi (2009) mengemukakan tentang kualitas dalam bidang pendidikan yang mempunyai kekhasan karakteristik, dengan pengertian pendidikan bukan sebagaimana dalam industri. Produk pendidikan adalah layanan atau services tidak barang atau goods, pelanggan atau users terdiri dari pelanggan internal yang terdiri dari guru, staff, tenaga kependidikan, dan pengelola, serta pelanggan eksternal yang terdiri dari siswa, wali siswa, masyarakat, pemerintah, dan pengguna lulusan. Pengguna di sini memerlukan perhatian yang lebih, karena sebagaimana konsep mutu adalah sesuai dengan keinginan pelanggan, maka lembag pendidikan diharapkan memenuhi kebutuhan, harapan, dan keinginan stakeholder. Secara lebih spesifik, pengguna yang utama dalam lembaga pendidikan adalah peserta didik. Mereka merupakan sebab utama diselenggarakannya proses pendidikan, selain itu mereka menjadi sebab keberadaan lembaga dan sistem pendidikan [17].

Proses pendidikan yang bermutu tinggi dilaksanakan dengan pengkoordinasian, penyerasian, serta perpaduan input sekolah (guru, siswa, kurikulum, uang, peralatan, dan sebagainya) dilakukan secara harmonis, sehingga mampu menciptakan situasi pembelajaran yang menyenangkan, mampu mendorong motivasi dan minat belajar, dan mampu memberdayakan peserta didik [1]. Depdikbud (2001) memberikan arti manajemen mutu terpadu berbasis sekolah adalah suatu pola model manajemen yang memberikan otonomi secara lebih besar terhadap sekolah dan mendorong pengambilan keputusan secara partisipatif yang melibatkan secara langsung semua warga sekolah untuk meningkatkan mutu sekolah berdasarkan kebijakan pendidikan nasional [1].

Proyeksi pengelolaan lembaga pendidikan dengan pendekatan mutu didasari suatu pemahaman bersama yaitu suatu institusi yang unggul dalam kompetisi global menghasilkan lulusan yang baik dan bermutu merupakan suatu keharusan dan kebutuhan. Suranto (2009) mengemukakan suatu gambaran lembaga pendidikan yang ideal dan dapat diterima oleh masyarakat yaitu lembaga pendidikan yang mempunyai keunikan yang dapat dipertanggungjawabkan, kesesuaian dengan kebutuhan pengembangan, memiliki nilai tambah, berinteraksi dengan lembaga lain, bertindak proaktif untuk berkembanga dan berubah, yang turut menghasilkan lulusan yang berguna [18].

Pada Total Quality Management atau TQM standar dibutuhkan untuk menjamin proses yang direncanakan dan disepakati bersama. Lebih dari hal tersebut pengelola memastikan bahwa seluruh pengurus memiliki karakter yang membudaya untuk memberikan layanan yang optimal kepada pelanggan. Sehingga peserta didik yang lulus atau lulusan tidak dimengerti sebagai produk pendidikan, akan tetapi sumber daya insani yang berkualitas dan dinamis. Demikian itu selaras dengan pendapat Mulyasa (2006) yang menyatakan bahwa lulusan yang telah menyelesaikan pendidikannya tidak saja dipengaruhi oleh mata pelajaran atau pengetahun dan keterampilan selama di sekolah, tetapi juga dipengaruhi oleh faktor-faktor lain dari lingkungan sekolah, mulai dari kinerja 
dan motivas guru, sikap pengelola pendidikan, latar belakang budaya dan tradisi juga lingkungan masyarakat yang dibentuk melayaninya [19].

Mengelola lembaga pendidikan dilakukan dengan memberikan layanan pendidikan. Orientasi terhadap peserta didik dipahami dengan memperlakukan mereka sebagai pelanggan. Pelanggan mengharapkan layanan yang optimal dengan diberikan kepuasan terhadap kebutuhan dan keinginannya. Kepuasan pelanggan merupakan tujuan yang menjadi pedoman para pengelola sekolah atau lembaga pendidikan. Tentu tidak semua keinginan pelanggan yang bebas atau semaunya saja, tetapi keinginan yang dikelola dengan strategi pencapaian melalui standar pelayanan kegiatan-kegiatan. Standar tersebut berfungsi menjadi kendali terhadap layanan yang diberikan, yang juga disepakati secara bersama oleh pengelola dan pelanggan. Pendidikan bermutu meliputi tindakan institusi pendidikan yang mampu memenuhi harapan pelanggan internal dan eksternal sebagaimana standar mutu yang berlaku dan disepakati bersama [1].

Praktik manajemen mutu dalam berbagai lembaga pendidikan memiliki perbedaan, akan tetapi perbedaan yang nampak hanya dalam cara atau strategi memberikan layanan. Sekolah-sekolah berkompetisi secara sehat dalam memberikan kualitas layanan yang unggul dari program dan kegiatan yang diselenggarakan untuk mewujudkan tujuan sekolah. Di antara layanan yang diberikan adalah upaya memperbaiki dan meningkatkan fasilitas sarana gedung dan prasarana pendukung yang proporsional bermutu, mengembangkan guru yang profesional, orientasi terhadap hasil belajar yang tinggi, lulusan yang memiliki kompetensi sebagaimana spesialisasi yang fokus pada kurikulum, dan pembiayaan pendidikan. Semuanya itu disebut sebagai 4Ps (place, people, product, price, and skills). Pada beberapa dekade terakhir, banyak sekolah swasta mengembangkan dan meningkatkan layanan yang diberikan kepada siswa dan wali siswa. Persaingan dalam memberikan layanan berimplikasi pada mutu lulusan. Lembaga dengan layanan yang bermutu, menghasilkan lulusan yang bermutu tinggi. Dengan pengelolaan sekolah berbasis implementasi manajemen mutu terpadu, maka mutu sekolah negeri dan sekolah swasta akan sangat bersain satu sama lain, tidak saja sekolah negeri yang unggul, tetapi juga sekolah swasta sangat berpotensi untuk unggul.

Upaya mewujudkan manajemen mutu terpadu dilakukan dengan mengaktualisasikan pilar manajemen mutu. Implementasi manajemen mutu dilakukan terhadap pengembangan kurikukulum menjadi pertimbangan dan perhatian serius. Sekolah yang bermutu memiliki 5 pilar mutu yaitu fokus, total, pengukur, komitmen, dan evaluasi. Dasar dari pilar tersebut adalah believe atau keyakinan dan nilai-nilai yang disepakati oleh warga sekolah secara bersama-sama, yang kemudian berkinerja dan bekerjasama dengan didorong oleh prilaku pimpinan atau kepemimpinan. Demikian itu sebagaimana diungkapkan Arcaro (2007) yang menyampaikan dalam pendidikan yang bermiutu tinggi membutuhkan tingkat keberadaan komitmen terhadap pelanggan internal dan eksternal yang mendapatkan kepuasan, selain itu diperkuat dengan komitmen untuk menciptakan lingkungan atau iklim oranganisasi yang memungkinkan warga sekolah dan pengelola dapat bekerjasama sebaikbaiknya. Ilustrasi dari praktik manajemen mutu terpadu [8].

\subsection{Kepemimpinan dalam manajemen mutu terpadu}

Purwanto mendefinisikan kepemimpinan yaitu kelompok rangkaian kemampuan dan merupakan sifat-sifat kepribadian, yang juga di dalamnya terdapat kewibawaan, untuk dimanfaatkan sebagai media meyakinkan orang-orang yang dipimpinnya agar mereka memiliki keinginan dan dapat menjalankan tugas-tugas tanggungjawab yang dibebankan kepadanya dengan terbuka, penuh motivasi, ada kebahagiaan batin, dengan tidak melakukannya dengan unsur keterpaksaan[20]. Adapun menurut Raihani, kepemimpinan sebagai proses memberikan pengaruh terhadap orang lain yang dilakukan dalam bentuk perilaku dan interaksi antara pimpinan dan bawahan, kegiatan ini terjalin dalam suatu konteks tertentu untuk mencapai tujuan dan cita-cita bersama [21].

Dari dua definisi tersebut dapat difahami bahwa kepemimpinan menjadi hal yang penting dalam pengelolaan mutu lembaga pendidikan. Kepemimpinan sebagai kemampuan dan sifat-sifat kepribadian menghasilkan suatu konsep gaya kepemimpinan. Sedangkan kepemimpinan sebagai suatu proses mempengaruhi menunjukkan suatu fungsi dari kepemimpinan. Pada penelitian yang akan dilakukan, peneliti memilih pada pendekatan kedua, yaitu kepemimpinan sebagai suatu proses mempengaruhi melalui fungsi-fungsi kepemimpinan pendidikan. Dalam konteks TQM, kepala sekolah diharapkan memiliki karakteristik pribadi yang baik dan positif. Kualitas karakter yang 
demikian itu memberikan inspirasi pada semua jajaran manajemen agar memperagakan kualitas kepemimpinan yang sama yang diperlukan dalam pengembangan budaya TQM [1].

Sallis mengemukakan peran kepemimpinan dalam mengembangkan budaya mutu yaitu dengan melakukan fungsi-fungsi kepempimpinan yang harus dilakukan yaitu; memiliki visi untuk institusi, memiliki kejelasan komitmen untuk mengembangkan mutu; memiliki kemampuan untuk menyampaikan pesan mutu; memenuhi kebutuhan pelanggan; memastikan bahwa suara dari pelanggan akan didengarkan; memimpin pengembangan staff; menghilangkan budaya menyalahkan; memimpin inovasi; memastikan bahwa struktur organisasi memiliki kejelasan definisi tanggungjawab dan menyediakan delegasi yang mumpuni dengan tingkat akuntabilitas yang baik; memiliki komitmen untuk menghilangkan hambatan termasuk dalam hal budaya; membangun kelompok kerja yang efektif; dan mengembangkan pola kerja yang sesuai dengan pengawasan dan evaluasi [10]. Mulyasa mengungkapkan ciri-ciri khusus kepala sekolah yang ideal yang terdiri dari orientasi yang tertuju pada kelompok, delegasi wewenang, melakukan stimuli untuk memunculkan kreatifitas, memberikan dukungan semangat dan motivasi, memiliki gagasan program penyertaan bersama, memiliki kreatifitas dan bertindak proaktif, memberikan perhatian pada sumber daya manusia, mendiskusikan kompetitor, membangun karakter, pola kepemimpinan yang tersebar, dan bekerjasama bersama masyarakat [1].

\subsection{Kepada sekolah sebagai leader dalam manajemen mutu terpadu}

Lembaga pendidikan formal sekolah memiliki pemimpin yang disebut kepala sekolah, adapun yang dipimpin adalah warga sekolah, kedua belah pihak ini secara bersama-sama bekerjasama mewujudkan tujuan sekolah. Dalam menjalankan kepemimpinan, kepala sekolah memiliki pola piker, asumsi, dan fungsi sebagai seorang pimpinan pendidikan. Sebagai pimpinan pendidikan, kepala sekolah termasuk dalam kategori sebagai leader atau formal leader dilihat dari status dan cara pengangkatannya, kedudukan ini memainkan peranan yang sangat penting. Sebagai pimpinan pendidikan pada sekolah dan warga sekolah yang memiliki tanggung jawab untuk membimbing, mengarahkan, dan memotivasi warga, kepala sekolah diharapkan untuk memiliki kualifikasi kompetensi memimpin, memiliki prilaku yang relevan sebagai teladan, dan keterampilan menjalankan proses kepemimpinan.

Kepala sekolah sebagai top leader memiliki alat yang melekat yaitu wewenang dan kekuasaaan, serta kompetensi untuk mengarahkan, membimbing, dan mengembangkan bawahannya secara profesional. Kepala sekolah memiliki kewajiban untuk menguasai kompetensi profesional yang terintegrasi dalam dirinya, kompetensi profesional tersebut adalah; 1) kompetensi sebagai pemimpin; 2) kompetensi sebagai manajer; 3) kompetensi sebagai pendidik; 4) kompetensi sebagai administrator; 5) kompetensi sebagai wirausahawan; 6) kompetensi sebagai pencipta iklim kerja; dan 7) kompetensi sebagai pemberi evaluasi [22]. Kemampuan pimpinan menuntut untuk dibuktikan dengan mengupayakan agar guru-guru dapat menjalankan tugas dan kewajibannya dengan baik dan berkelanjutan. Demikian itu dilakukan dengan membagi kewenangan yang dimiliki kepada guru-guru yang sesuai dengan hak dan kewajiban. Keterampilan kepemimpinan dibuktikan dengan kinerja kepala sekolah yang melakukan tugas dan tanggungjawab sesuai dengan peraturan dan budaya sekolah, menjalin komunikasi antara warga sekolah dengan baik, juga mengambil kebijakan yang bebas dari kecenderungan atau kepentingan individu dalam organisasi.

Upaya-upaya yang dilakukan oleh kepala sekolah sebagai leader terhadap guru dan warga sekolah sangat terkait dengan kepemimpinan yang dijalankan. Fokus orientasi tindakan yang dilakukan pada peningkatan mutu lembaga menjadi prioritas dalam meletakkan kepentingan dan kebijakan pengembangan yang didasari oleh pola kepemimpinan. Indikator menuju pengembangan mutu dilaksanakan dalam pola-pola interaksi yang dibangun secara bersama-sama antara guru-guru, peserta didik, dan tenaga kependidikan. Keunggulan-keunggulan yang dimiliki oleh setiap individu berikut kekurangannya menjadi perhatian untuk ditingkatkan dan diperbaiki. Demikian itu tidak mudah bagi seorang pemimpin, banyak harapan dan impian yang menuntut untuk dipenuhi dari pimpinan. Keterbatasan sumber daya dan sumber dana memutar otak pimpinan agar terus berkinerja agar berbagai masalah dapat diselesaikan. Kemampuan pimpinan memberikan solusi dan menyelesaikan permasalahan merupakan kepuasan pimpinan. Kesadaran akan pentingnya pimpinan sebagai leader merupakan hal yang penting, yang juga menjadi tantangan dalam menjalankan tugas dan membawa warga sekolah pada pencapaian rencana strategis yang telah disusun dan disepakati bersama. 
Wawancara dan observasi dilakukan oleh peneliti di SD Muhammadiyah Pendowoharjo pada kepala sekolah terkait objek penelitian. Kepala sekolah menceritakan elemen-elemen penting manajemen mutu terpadu yang telah dilakukan sebagai usaha untuk mewujudkan tujuan lembaga yang efektif dan efisien, dengan prioritas utama pada peningkatan mutu lembaga. Untuk tujuan tersebut, kepala sekolah melakukan peran sebagai seorang leader, yaitu dengan memberikan suatu pengetahuan dan pemahaman pikiran pokok orientasi mutu terpadu kepada warga sekolah yang disebut dengan pelanggan. Pelanggan di sini dimaksudkan pelanggan internal dan eksternal, pelanggan internal yaitu; guru-guru dan tenaga kependidikan, sedangkan pelanggan eksternal yaitu; peserta didik, wali murid, masyarakat, pemangku kebijaikan, dan pengguna lulusan.

Kepala sekolah mensosialisasikan berbagai kegiatan sekolah kepada unsur-unsur yang memiliki hubungan dengann kegiatan tersebut terkait dengan mutu layanan terhadap pelanggan. Kegiatan tersebut dijelaskan arah tujuan, manfaat, dan strategi yang dipilih dalam forum rapat sekolah secara internal, rapat internal sekolah bersama komite dan orang tua siswa pada kegiatan tahunan; awal tahun pembelajaran, pertengahan semester, dan pada akhir tahun pembelajaran sebagai bentuk laporan evaluasi kegiatan dalam satu tahun pmbelajaran. Pada perkumpulan atau rapat yang diselenggarakan, kepala sekolah menyampaikan visi dan misi dari sekolah yang terkait dengan kegiatan yang akan atau telah dilakukan. Tidak lupa, pada penyampaian tersebut, kepala sekolah menghubungkan antara program kegiatan, tujuan dan sasaran kegiatan, orientasi mutu kegiatan, dan visi-misi sekolah. Para murid, guru, dan wali murid yang menghadiri kegiatan sosialisasi menyimak arahan yang disampaikan oleh kepala sekolah. Perkumpulan-perkumpulan dalam bentuk formal dan non-formal merupakan media yang efektif bagi kepala sekolah untuk menyampaikan sosialisasi pengembangan mutu sekolah.

Terdapat dua bentuk rapat yang diselenggarakan di sekolah, dilihat dari sudut pandang peserta rapat yang terlibat, yaitu; rapat internal yang dihadiri oleh guru-guru dan tenaga kependidikan, dan rapat eksternal yang dihadiri oleh wali siswa, siswa, bersama guru-guru, pengurus sekolah dan tenaga kependidikan. Pembedaan ini berimplikasi pada materi dari rapat yang dilakukan, tetapi sekalipun berbeda secara materi, hal-hal yang disampaikan secara substantif adalah terkait dengan pengembangan mutu sekolah.

Pada kegiatan rapat dan koordinasi, kepala sekolah memberikan support dalam bentuk motivasi kepada guru-guru dan warga sekolah. Motivasi tersebut disampaikan dengan harapan agar mereka memahami betul perannya yang sangat signifikan terhadap keberhasilan sekolah. Selain daripada itu, mengingat masa kerja guru yang sudah relatif lama, tidak dapat dipungkiri bahwa motivasi guruguru terkadang naik dan turun. Pada suatu kondisi tertentu, kepala sekolah memanggil seorang guru atau tenaga kependidikan untuk diberikan bimbingan mengenai evaluasi kinerja atau peningkatan kinerja.

Hubungan yang dibangun antara kepala sekolah dengan warga dan stakeholder sekolah adalah hubungan yang dinamis dan kekeluargaan. Pada saat-saat tertentu di sekolah pendekatan dilakukan secara struktural yang menyelaraskan antara jabatan dan tugas yang melekat pada jabatan tersebut. Tetapi pada saat yang lain pendekatan dilakukan dengan pola kekeluargaan di mana sesama guru saling memosisikan sebagai saudara yang mengingat satu sama lain tentang hal-hal yang diperkenankan dan yang tidak diperkenankan. Dua model pendekatan ini terbukti efektif dalam mengarahkan warga sekolah untuk melaksanakan kegiatan-kegiatan sesuai dengan tujuan yang dirumuskan.

Hal lain yang dilakukan terkait kinerja kepala sekolah sebagai leader adalah senantiasa berproses dan berusaha meningkatkan kompetensi para tenaga pendidik dan kependidikan dengan memberikan kesempatan untuk mengikuti kegiatan-kegiatan pelatihan dan workshop. Keikutsertaan guru-guru dalam pengembangan sumber daya manusia diharapkan dapat mendukung peningkatan kinerja sekolah. Mereka sangat antusias dalam mengikuti berbagai kegiatan yang difasilitasi oleh kepala sekolah. Bagi guru-guru, demikian itu merupakan suatu bentuk kepercayaan yang sangat berharga. Sehingga menimbulkan rasa bahwa mereka merupakan bagian yang tak terpisahkan bagi peningkatan mutu sekolah. Sedangkan bagi tenaga kependidikan, yang demikian itu membantu mengatasi problematika yang dihadapi pada saat melakukan pekerjaan. Kegiatan pelatihan yang diberikan memberikan jawaban terhadap kesulitan-kesulitan yang dihadapi pada saat bekerja. 
Berdasarkan paparan tersebut, dapat dipahami bahwa secara sistematis nilai-nilai manajemen mutu yang telah diimplementasikan oleh kepala sekolah sebagai leader di SD Muhammadiyah Pendowoharjo Sewon Bantul adalah; a) Fokus pada warga sekolah sebagai pelanggan internal dan eksternal sesuai dengan proporsi masing-masing; b) Memiliki keinginan yang kuat dan realistis terhadap kualitas atau mutu; c) Memberikan kepercayaan secara penuh kepada guru-guru dan tenaga kependidikan untuk berinovasi dan tidak bertentangan dengan budaya sekolah; d) Melakukan perbaikan berkelanjutan yang disampaikan dalam forum-forum rapat internal dan eksternal; dan e) Mengembangkan guru-guru dengan mengikutsertakan pada kegiatan-kegiatan pelatihan dan workshop.

Kepala sekolah melakukan berbagai tugas dan kewajibannya untuk mempengaruhi warga sekolah agar memahami dan menyadari kewajiban dan tanggungjawab, berkinerja sesuai rencana dan tujuan sekolah. Demikian itu selaras dengan fungsi kepala sekolah sebagai leader atau pemimpin [23]. Di sini menunjukkan peran kepempimpinan yaitu untuk menggerakkan warga organisasi agar sadar terhadap tugas dan fungsinya masing-masing sebagai bentuk usaha untuk mencapai tujuan bersama. Demikian itu sesuai dengan kriteria kepemimpinan kepala sekolah yang efektif, sebagaimana disebutkan oleh Mulyasa yaitu; 1) Pemberdayaan tenaga pendidik dan kependidikan untuk mengelola pembelajaran yang bermutu, tanpa kendala, dan menghasilkan produktifitas; 2) Bekerja sama dan saling membantu dengan pengelola manajemen sekolah [1]. Proses pemberdayaan sumber daya manusia di sekolah yang dilakukan oleh kepala sekolah merupakan upaya memberikan pengalaman dan kesempatan kepada warga sekolah agar turut berkontribusi terhadap implementasi dan pengembangan mutu sekolah.

Kinerja kepala sekolah sebagai leader dalam manajemen mutu terpadu di sekolah Muhammadiyah Pendowoharjo diorientasikan dalam pengelolaan tenaga pendidik dan kependidikan yang bermutu. Mutu pengurus sekolah menjadi keharusan untuk terus ditingkatkan dan dikembangkan. Pengembangan dan peningkatan yang dilakukan tidak dibatasi pada kekurangan guru pada kegiatan belajar dan mengajar, akan tetapi pada kebutuhan untuk perkembangan sekolah di masa yang akan datang.

\section{Kesimpulan}

Kepemimpinan memiliki peran yang sangat signifikan dalam mengembangkan pola manajemen mutu terpadu di SD Muhammadiyah Pendowoharjo. Kinerja kepala sekolah sebagai leader mengembangkan mutu pendidikan secara terpadu dilakukan dengan cara; 1) mengarahkan kepada guru dan tenaga kependidikan agar visi-misi dan tujuan dijadikan sebagai dasar dan arah yang menggerakkan kegiatan dan menyusun program; 2) memotivasi warga sekolah untuk berkinerja secara optimal; 3) pembinaan diberikan kepada tenaga pendidik dan kependidikan secara struktural dan kekeluargaan untuk berkontribusi secara positif terhadap pengembangan mutu sekolah; dan 4) memberikan fasilitas kegiatan workshop, pelatihan, dan pengembangan terkait kebutuhan guru yang membutuhkan pengembangan dalam meningkatkan kualitas diri dan mutu lembaga pendidikan.

\section{Referensi}

[1] H. . Mulyasa, Manajemen dan Kepemimpinan Kepala Sekolah. Jakarta: Bumi Aksara, 2011.

[2] R. Ekosiswoyo, "Kepemimpinan Kepala Sekolah yang Efektif Kunci Pencapaian Kualitas Pendidikan,” J. Ilmu Pendidik., vol. 14, no. 2, pp. 76-82, 2007.

[3] M. Abdullah, "Manajemen Mutu Pendidikan Di Sekolah Peran Kepemimpinan Kepala Sekolah, Profesionalisme Guru, Dan Partisipasi Masyarakat Dalam Peningkatan Mutu Pendidikan Di Sekolah,” J. Penelit. Pendidik., vol. 17, no. 3, pp. 190-198, 2018.

[4] E. Manik and K. Bustomi, "Budaya Organisasi Dan Motivasi Kerja Terhadap Kinerja Guru Pada Smp Negeri 3 Rancaekek,” J. Ekon. Bisnis Entrep., vol. 5, no. 2, pp. 97-107, 2011.

[5] S. Setiyati, "Pengaruh Kepemimpinan Kepala Sekolah, Motivasi Kerja, dan Budaya Sekolah Terhadap Kinerja Guru," J. Pendidik. Teknol. dan Kejuru., vol. 22, no. 2, pp. 200 207, 2014. 
[6] I. Khadijah, "Manajemen Mutu Terpadu (TQM) Pada Lembaga Pendidikan Islam," Al Idarah; J. Kependidikan Islam, vol. 05, no. 01, pp. 58-75, 2015.

[7] S. Sagala, Manajemen Strategik dalam Peningkatan Mutu Pendidikan. Bandung: Alfabeta, 2010 .

[8] J. S. Arcaro, Pendidikan Berbasis Mutu; Prinsip - prinsip Perumusan dan Tata Langkah Penerapan. Yogyakarta: Pustaka Pelajar, 2007.

[9] H. Nawawi, Manajemen Strategic Organisasi Non Profit Bidang Pemerintahan Ilustrasi Dibidang Pendidikan. Yogyakarta: Gajah Mada University Press, 2003.

[10] E. Sallis, Total Quality Management in Education, Third Edit. London: Taylor \& Francis eLibrary, 2005.

[11] E. Yusmina and M. Ar, "Implementasi Manajemen Mutu Terpadu Dalam Peningkatan Kinerja Sekolah Pada Smk Negeri 1 Banda Aceh," J. Adm. Pendidik. Progr. Pascasarj. Unsyiah, vol. 2, no. 2, pp. 168-178, 2014.

[12] M. Fadhli, "Manajemen Peningkatan Mutu Pendidikan," Tadbir J. Stud. Manaj. Pendidik., vol. 1, no. 2, p. 215, 2017.

[13] M. Juliantoro, "Peran Kepala Sekolah Dalam Meningkatkan Mutu Pendidikan," J. alHikmah, vol. 5, no. 2, pp. 24-38, 2017.

[14] M. Fitrah, "Peran Kepala Sekolah Dalam Meningkatkan Mutu Pendidikan," J. Penjaminan Mutu, vol. 3, no. 1, pp. 31-42, 2017.

[15] H. Iqbal, Pokok-pokok Materi Metodologi Penelitian dan Aplikasinya. Jakarta: Ghalia Indonesia, 2002.

[16] L. J. Moleong, Metodologi Penelitian Kualitatif. Bandung: Remaja Rosda Karya, 2002.

[17] Suryadi, Manajemen Mutu Berbasis Sekolah. Bandung: Sarana Panca Karya Nusa, 2009.

[18] Suranto, Manajemen Mutu dalam Pendidikan (QM in Education). Semarang: CV. Ghayas Putra, 2009.

[19] E. Mulyasa, Manajemen Berbasis Sekolah. Bandung: Remaja Rosda Karya, 2006.

[20] N. Purwanto, Administrasi dan Supervisi Pendidikan. Bandung: Remaja Rosda Karya, 1993.

[21] Raihani, Kepemimpina Sekolah Transformatif. Yogyakarta: LKiS, 2011.

[22] T. Tim Kerja Kepala Sekolah, Standar Kompetensi kepala Sekolah TK, SD, SMP, SMA, SMK, dan SLB. Yogyakarta: Pustaka Yustisia, 2007.

[23] S. Budiwibowo and S. Sudarmiani, Manajemen Pendidikan. Yogyakarta: Andi Offset, 2018. 